\title{
The Note Issue Paradox in the Free Banking Era
}

Howard Bodenhorn AND Michael HaUPERT

In recent years a number of papers have appeared offering explanations of the long-noted, long-unresolved note issue paradox in both the free and national banking eras. ${ }^{1}$ Some have argued that previous profit calculations overstate the true cost of note issue because they fail to account for risks and costs that are not easily modeled. ${ }^{2}$ Others have argued that profit calculations are reasonably accurate and demonstrate that the bankers acted irrationally in failing to reap easily gathered profits. ${ }^{3}$ Yet another approach radically modified the basis of the calculation and found potential profits to be quite small. ${ }^{4}$ This note offers an explanation overlooked by most previous studies: that although note issue was profitable, a more profitable avenue existed. ${ }^{5}$ Because of legal and institutional restrictions, banks found it more profitable at the margin to create deposits rather than issue notes in extending credit.

\section{LOOKING FOR THE PARADOX}

The standard approach in determining note issue profitability has been to calculate the marginal profit from additional issues. In expanding their circulation, banks faced a portfolio decision; they could expand note issues either through reductions in other earning assets or through new equity. ${ }^{6}$ Under either alternative a bank had to purchase collateral bonds, which were placed on deposit with the state comptroller. The comptroller then forwarded notes to the bank equal in value to a percentage of the par or market price of the tendered bonds. So long as the bank remained solvent and promptly met redemption demands, banks received the coupon interest payments. Increased note issue therefore implied increased revenues equal to $r_{B} p$, where $r_{B}$ represents the yield on a collateral bond and $p$ its price.

But note issue was not costless. Direct costs included engraving and printing costs as well as the time value of bank presidents and cashiers who countersigned each note and of tellers who registered them. Such costs for national banks amounted to 6.25 cents per $\$ 100$

The Joumal of Economic History, Vol. 56, No. 3 (Sept. 1996). O The Economic History Association. All rights reserved. ISSN 0022-0507.

Howard Bodenhorn is Assistant Professor of Economics, Lafayette College, Easton, PA 18042. Michael Haupert is Associate Professor of Economics, University of Wisconsin, La Crosse, La Crosse, WI 54601.

We would like to thank Charles Calomiris, Lynn Kiesling, Hugh Rockoff, participants at seminars at Columbia, Northwestern, Rutgers, Washington University, and the University of Glasgow, in addition to Naomi Lamoreaux and two anonymous referees for helpful comments and suggestions. The usual caveat applies.

'The earliest recognition and explanation is Bell, "Profit."

2 Bodenhorn and Haupert, "Conundrum;" Champ, Underissue; and Kuehlwein, "National Bank Note Controversy."

${ }^{3}$ Cagan and Schwartz, "National Bank Note Puzzle."

${ }^{4}$ Champ, Wallace, and Weber, "Resolving."

s James, "Conundrum," argued that deposit creation was more profitable than note issue for national banks, but later studies have not advanced his thesis.

${ }^{6}$ The analysis in this note is based on the New York free banking system, in operation from 1838 to 1861 . Although the reference to laws and regulations regarding the banking institution are specific to the state of New York during this period, much of the argument can be generalized to other free banking states, many of which modeled their systems closely on the New York system.

687

The Journal of Economic History (1996), 56 : 687-693 Cambridge University Press

doi:10.1017/S0022050700016995/

http://journals.cambridge.org/action/displayAbstract?fromPage=online\&ai $\mathrm{d}=4135424 \&$ fulltextType $=$ RA\&fileId $=$ S0022050700016995 
in notes. Although not all analogous costs included in national bank note calculations can be found, a lower-bound cost for free banks was about 7.81 cents per $\$ 100$. $^{7}$

In addition, new note issues forced changes in bank balance sheets, creating indirect costs. If collateral-bond purchases were financed by reductions in other earning assets, indirect costs were the product of foregone income and the difference between the reduction in those alternative assets and the increase in revenue-producing loans financed through new note issues. For New York free banks, the difference could be substantial. If a bank bought and deposited with the state comptroller a 6 percent bond with a par value of $\$ 100$, the bank received notes equal to the minimum of either market or par value. Because most New York and U.S. bonds sold above par, potential note issues were less than the price of the bond. In addition, bonds paying less than 6 percent were accepted at rates making them equivalent to 6 percent securities. A 5 percent bond, for example, was accepted at only five-sixths of the minimum of par or market value. Potential note issues were then equal to $\alpha \min (p, 100)$, where $0 \leq \alpha \leq 1$ was the ratio of allowable note issue to par value (that is, $\alpha=1$ for 6 percent bonds, $\alpha=5 / 6$ for 5 percents, and so on), and $\min (p, 100)$ was the value at which bonds were accepted on deposit by the state comptroller (market or par).

Although most studies recognized the potentially large differences between bond price and note issue, many overlooked another cost-namely the bank holding idle notes during seasonal or cyclical downturns in loan demand. Free banks were rarely able to keep all of their allowable note issues in circulation at all times. Ratios of idle notes to total legal circulation in New York ranged from a low of 4 percent in 1852 to a high of 21.6 percent during the panic of 1857 . The proportion of idle notes dipped below 10 percent in only three years and hovered around 15 percent throughout the $1850 \mathrm{~s}$.

Furthermore, measures had to be taken to ensure that additional notes in circulation could be redeemed. For banks outside New England and New York, this meant holding larger specie reserves. In New England and New York, special redemption systems arose. New England had the endogenously created Suffolk system, which, although not requiring bonds to back up note issue, did impose other costs on banks. New York legally imposed a similar system. In New York, few notes were redeemed at a bank's counter. Country banknotes tended toward New York City where most country banks held redemption accounts. Several city banks acted as redemption agents, accepting country bank notes at par as long as the country bank maintained sufficient balances, and this eventually became the dominant method of redemption in New York. ${ }^{8}$ Additional note issues then meant acquiring and forwarding additional redemption balances to city correspondents.

Between 1845 and 1861 New York's country banks held average redemption balances equal to about 44 percent of their actual circulation. If marginal additions equaled average balances, an additional dollar of note issue required a 44-cent increase in city redemption funds. Such funds had an explicit opportunity cost in that they were tied up as redemption balances instead of used to purchase earning assets. A handful of city banks paid interest on redemption balances that somewhat mitigated this opportunity cost, but most did not. ${ }^{9}$

An appropriate rate of return to note issue calculation should then account for all revenues and costs, including the presence of idle notes and the opportunity costs of

${ }^{7}$ These costs were estimated using data for Virginia banks in 1838 and New York free banks in the $1850 \mathrm{~s}$. Those interested can obtain a data appendix from the authors.

${ }^{8}$ New York Assembly, "Annual Report," p. 6.

9 James, "Note," found interbank deposit rates were a relatively constant 2 percent after 1870. Before 1870 rates were higher ( 3 to 6 percent) among banks that paid interest, but as most banks did not pay interest, the average was probably well below the stated 3 to 6 percent rates. On the other hand, banks paying interest probably attracted the lion's share of redemption funds. Fully resolving this issue would require more work than justified by any effect it might have on rates of return. James's 2 percent value was used. In using the lower value, potential returns are understated. If rates exceeded 2 percent, the term $\left(r_{A}-r_{B}\right)$ decreases, the numerator increases, and the estimated rate of return rises. 
holding additional reserves. Pulling all these terms together results in a return to note issue expressed as

$$
\begin{gathered}
r=\left[r_{B} p-c \alpha \min (p, 100)-r_{A}(p-\rho \alpha \min (p, 100))-\left(r_{A}-r_{R}\right) \theta \rho \alpha \min (p, 100)\right] /[p \\
-\rho \alpha \min (p, 100)]
\end{gathered}
$$

where $c$ is the direct cost of a marginal note issue, $r_{A}$ is the rate that redemption funds could have earned in alternative employments, and $r_{R}$ is the interest rate on interbank balances. ${ }^{10}$ The term $0 \leq \theta \leq 1$ is the ratio of city redemption funds to total circulation, and $0 \leq \rho \leq$ 1 is the ratio of idle notes to allowable note issues based on the deposit of a collateral bond of price $p$.

Table 1 reports estimates of the rate of return to marginal note issue based on the prices and yields of a representative and widely held collateral bond-United States 6s of 1862. Rates of return to note issue found here are considerably lower than those reported in most previous studies, but they are not so low as to resolve the paradox. At the same time, rates of return based on holding of other collateral bonds (not reported) were as high or higher than those reported in Table $1 .^{11}$ Returns ranging from slightly less than 10 percent in the mid-1850s to about 30 percent in 1847 and 1848 went unexploited by banks. Such a finding begs the obvious question: why did bankers leave unexploited such promising and profitable opportunities?

\section{RESOLVING THE PARADOX}

Earlier resolutions of the national banking era note issue paradox have focused on two risks not easily captured in rate-of-return calculations like equation 1 . One was the risk that the circulation provision may have been revoked. Although it is unlikely that a majority of any state's legislators would have seriously considered revoking the note issue privilege during the antebellum era, free banking could have been rescinded. Moreover, the continuance of free banking in New York was at no time guaranteed.

New York's free banking law had not been passed in accordance with the state constitutional guidelines, and questions lingered throughout free banking's heyday about the legal standing of the system. Several disgruntled and delinquent creditors attempted to escape asset attachments by challenging the law's constitutionality, but judges sympathetic to free banking artfully sidestepped the issue. ${ }^{12}$ These were short-term victories, but they never secured the banks' legal standing. Even as late as 1857, the state's banking superintendent considered free banks "anomalous, objectionable, and of doubtful legality."13

Hanging in legal limbo placed the banks in an unsavory position. A finding that free banking violated the state's constitution might have required the forced closing of over 100 free banks, precipitating the sale of their collateral bonds on relatively thin markets. Should the law have been struck down, significant capital losses would have been imposed on shareholders, so it is not surprising that risk-averse bankers were unwilling to increase their note issues. That the prices of eligible bonds were inflated because they carried the note issue privilege only exacerbated the risks.

Bankers also feared their legislatures. What the legislature gave, it could take away; and New York State had a habit of changing the rules. Between 1784 and 1829 the legislature granted bank charters in return for bonus payments. In 1829 it instituted the Safety Fund.

${ }^{10}$ To simplify the calculation, $r_{A}$ was assumed constant at 6 percent and $r_{R}$ at 2 percent. Market interest rates $\left(r_{A}\right)$ varied during the 1840s and 1850s, but Bodenhorn and Rockoff, "Regional Interest Rates," found that they averaged about 6 percent.

${ }^{11}$ See Bodenhorn and Haupert, "Note Issue Conundrum," table 1, p. 706.

${ }^{12}$ Ibid. pp. 707-10.

${ }^{13}$ Hammond, Banks, p. 587. 
TABLE 1

PERCENTAGE RATES OF RETURN TO NOTE ISSUE AND DEPOSIT CREATION

\begin{tabular}{llrr}
\hline \hline & Qtr & Note & Deposit \\
Year & Issue & Creation \\
\hline 1845 & I & 12.0 & 16.9 \\
& III & 15.2 & 16.2 \\
1846 & I & 17.5 & 17.7 \\
& III & 25.7 & 15.4 \\
1847 & I & 29.7 & 21.5 \\
& III & 25.9 & 14.9 \\
1848 & I & 29.4 & 33.4 \\
& III & 26.3 & 33.1 \\
1849 & I & 19.3 & 34.2 \\
& III & 16.6 & 17.2 \\
1850 & I & 16.1 & 21.2 \\
& III & 14.0 & 23.9 \\
1851 & I & 15.3 & 27.8 \\
& III & 15.9 & 46.8 \\
1852 & I & 14.3 & 29.2 \\
& III & 10.7 & 24.5 \\
1853 & I & 10.3 & 35.1 \\
& III & 8.5 & 55.6 \\
1854 & I & 8.6 & 48.3 \\
& III & 11.7 & 59.0 \\
1855 & I & 12.5 & 33.8 \\
& III & 9.8 & 32.2 \\
1856 & I & 11.8 & 31.3 \\
& III & 9.6 & 47.3 \\
1857 & I & 10.0 & 50.7 \\
\hline
\end{tabular}

Notes: See equations 1 and 2 and the text for the derivation of rate-of-return calculations. Quarter I returns are based on averages of weekly bid prices for U.S. 6s of 1862 for March. Quarter III returns have the same basis for September. The rate-of-return equations are given in the text. The calculations are based on the following assumptions: $r_{A}=$ yield on alternative investments (assumed to be constant at 6 percent); $r_{B}=$ yield to maturity on U.S. $6 \mathrm{~s}$ of $1862 ; r_{L}$ is the rate on high-grade commercial paper in New York City; $r_{R}=$ the interest payments on redemption balances (assumed to be constant at 2 percent); $\rho=$ the percentage of notes in circulation to the total authorized issue (assumed to be constant at 88 percent); $\theta=$ the ratio of city redemption balances to the note issue (assumed to be constant at 44 percent); $c \alpha \min (p, 100)=$ the cost per $\$ 100$ of the note issue (assumed to be constant at 7.81 cents).

Sources: Albany Argus, 1845-1854; Bicknells, 1845-1857; Bodenhorn, "Capital Mobility"; New York Daily Times, 1850-1861; and New York Herald, 1850-1860.

Within a decade it imposed free banking. Statutory change was the only constant in New York banking and smart bankers surely recognized this. But concerns about the revocation of free banking were not confined to New York. In many states the general attitude was that the continuation of free banking hung on keeping radical Democrats in the legislative minority. Although Bruce Champ was referring to postbellum-era national banks when he noted that bankers "would have been extremely naive to believe that the circulation privilege could not be revoked," the point applies, in modified form, to antebellum free bankers as well. ${ }^{14}$

The second risk not captured by standard rate-of-return calculations was the capital risk faced by free banks. Two features of bond-secured note issue created substantial risks for banks intermediating long-term government debt into demand liabilities. One was the

\footnotetext{
${ }^{14}$ Champ, Underissue, p. 46.
} 


\section{The Note Issue Paradox in the Free Banking Era}

variability of both note redemptions and bond prices. If a bank witnessed an unexpected specie drain, it would be forced to raise additional specie in some way. Calling loans was generally viewed as unreliable and unacceptable, so the bank's only alternative would be to surrender its redeemed notes in order to recover collateral bonds from the state comptroller. It could then sell the bond and meet further redemption calls. The prospect of selling bonds, particularly in thin markets, meant that bond price fluctuations were a constant concern for bankers, and being forced to sell them in the midst of a financial crisis implied significant capital losses for the bank. Sharp price fluctuations and the resulting volatility of yields during the antebellum era were at least partly responsible for the relatively low issue of notes among free bankers.

Sharp bond price fluctuations also exposed banks to duration-gap or term-structure risks. Antebellum bank loans generally ran 60 to 90 days, so that sudden and unexpected macroeconomic shocks were unlikely to lessen seriously their market value. Long-term bonds were another matter. A bank investing the lion's share of its capital in long-term government debt could quickly suffer a significant decrease in the market value of its assets; and if bond prices fell sufficiently, a bank might suffer a depletion of its entire net worth. If noteholders and depositors recognized the detrimental balance sheet effects of rising interest rates, they faced incentives to cash out as quickly as possible, forcing the bank's closing. Arthur Rolnick and Warren Weber, in fact, found that most free bank closings occurred during periods of falling bond prices. ${ }^{15}$ Bankers were, then, understandably wary of holding large numbers of state bonds.

\section{AN ALTERNATIVE RESOLUTION OF THE PARADOX}

Although termination and term-structure risks were certainly important factors that influenced free bankers' decisions, they may not fully resolve the paradox, thereby leaving bankers open to the charge that they acted irrationally in not issuing more notes. ${ }^{16} \mathrm{~A}$ more satisfying solution may be that note issue was dominated by a superior alternative. Previous studies all treated the paradox in the same manner: buying bonds to issue notes was a "pure arbitrage opportunity." ${ }^{17}$ Banks had simply to invest in government debt, arbitrage it into banknotes, and then put them in circulation. It is vexing that profits in excess of 50 percent went unexploited if it was pure arbitrage. But, as Bray Hammond noted, it was not.

[B]anks were so often spoken of as "putting their notes in circulation" that it sounds as if their doing so were an end in itself and presupposed nothing more than perhaps their thrusting the notes out the window to be caught by the wind. Quite to the contrary, the circulation was necessarily incidental to the accomplishment of loans, purchases, or other transactions that gave them earning assets in return. ${ }^{18}$

Increasing its note issue was not pure arbitrage for a bank. Putting more notes in circulation required greater extensions of credit. ${ }^{19}$

How did New York's banks extend credit? Between 1845 and 1860 the value of loans increased from about $\$ 60$ million to more than $\$ 200$ million, whereas note issues increased from only $\$ 18$ to $\$ 28$ million. Over the same period the value of deposits increased from $\$ 26$ to $\$ 110$ million. If issuing notes was incidental to the accomplishment of loans, it is apparent that deposit creation was too. Given note issue's apparent profitability, why did

\footnotetext{
${ }^{15}$ Rolnick and Weber, "Free Banking," pp. 15-18.

${ }^{16}$ See Bodenhorn and Haupert, "Note Issue Conundrum," pp. 705-07; and Cagan and Schwartz, "National Bank Note Puzzle."

${ }^{17}$ Champ, Wallace, and Weber, "Resolving," p. 14.

${ }^{18}$ Hammond, Banks, p. 694.

${ }^{19}$ Extending more credit also entailed greater risks. If a bank increased its loans, it probably meant accepting more marginal paper in return. This presents another risk in addition to the ones discussed earlier.
} 
banks choose to extend credit in the form of deposits? The answer is that, when judged on the same basis as note issue, deposit creation was more profitable.

Just as issuing notes required rearranging a bank's portfolio, creating deposits required similar adjustments. If a bank wished to increase its lending by an amount $\Delta L$, it could do so either by laboring through the collateral-bond process, or it could simply create a deposit. But banks were also required to rearrange their portfolios when creating deposits. They had to account for expected net withdrawals of reserves consistent with their increased deposits. If net withdrawals were equal to $\gamma \Delta L$, where $0 \leq \gamma \leq 1$, they either had to reduce other earning assets by $\gamma \Delta L$ or inject new capital. In either case, resources committed to reserves could have been earning income in another employment. It was not a legal requirement imposed by the state, but rather a prudent action employed by conservative bankers that led to this increase in reserves. Expanding banks, therefore, sacrificed income equal to $r_{B} \gamma \Delta L$, where $r_{B}$ was the income to be earned in the next-best alternative investment. A rate of return to deposit creation comparable to the note issue calculation in equation 1 above is then ${ }^{20}$

$$
r_{\text {deposits }}=\left(r_{L} \Delta L-r_{B} \gamma \Delta L\right) / \gamma \Delta L
$$

where $r_{L}$ is the going loan rate.

Rates of return to deposit creation, assuming reductions in bond holdings, are presented in Table $1 .{ }^{21}$ Returns to deposit creation ranged from a low of about 15 percent in 1847 to a high of 59 percent in 1854. Comparing the rates of return to note issue and deposit creation also show that they were approximately equal in 1845 and 1846. In 1847 and 1848 note issue dominated, but by 1849 deposit creation became more profitable and remained so throughout the remainder of the antebellum era.

It is thus not surprising that banks failed to exploit the profits to be gotten from additional note issues. It was not necessarily that risk-adjusted rates of return were low (as they may well have been), but that returns from deposit creation dominated. This relatively straight-forward conclusion has probably been overlooked by other students of the paradox because they viewed note issue as an arbitrage function. Clearly it was not. It was part and parcel of the lending process, as was deposit creation. So long as deposit creation entailed lower costs, lesser risks, and greater returns, banks preferred deposit creation to note issue.

Given the greater profitability of deposit creation, why would banks persist in issuing any notes at all? We can think of four reasons why this behavior would persist. First, notes were demanded by customers for use in local transactions as hand-to-hand currency; therefore, banks needed to maintain enough notes in circulation to meet these needs. In addition, retiring notes from circulation could be an expensive proposition, especially if the sudden recall of notes was viewed by the public as a portent of impending trouble. Issuing notes was also a way of attracting specie and served as a means of diversifying a bank's portfolio. Finally, notes in circulation, because they bore the name of the bank, served as a valuable means of advertisement for the bank.

\section{CONCLUDING REMARKS}

We have shown that free banks, like national banks, failed to issue more notes despite its apparent profitability. Resolutions like those offered to explain national bank behavior are seen to apply with equal validity to free banks. But unlike other resolutions of the paradox, we argue that there existed a close (but imperfect) substitute for banknotes-

${ }^{20}$ It was assumed that no interest was paid on created deposits.

${ }^{21}$ It was assumed that the marginal loan increase was $\$ 100$, making the calculations comparable to the note issue case. Most eligible bonds had a par value of $\$ 100$, and most of the better grades of 6 percent bonds sold above par. Therefore, marginal note issues were $\alpha \min (p, 100)$ which was $\$ 100$ or less. 
namely, created deposits. Our results suggest that it was the greater returns to be earned through deposit creation that induced antebellum banks to issue seemingly fewer than an optimal volume of notes. When viewed in this light, the note issue conundrum disappears. It is no longer necessary to search out additional hidden costs or risks of note issue, nor does the weak reed of irrationality hold up. Rather, bankers passed up note issue profits because, at the margin, a more profitable alternative existed.

\section{REFERENCES}

Albany Argus, various issues, $1845-1854$.

Bicknell's Counterfeir Detector, Bank Note Reporter and General Price Current, various issues, 1845-1857.

Bell, Spurgeon. "Profit on National Bank Notes." American Economic Review 2, no. 1 (1912): 38-60.

Bodenhorn, Howard. "Capital Mobility and Financial Integration in Antebellum America." this JouRNAL 52, no. 3 (1992): 585-610.

Bodenhorn, Howard, and Michael Haupert. "Was There a Note Issue Conundrum in the Free Banking Era?" Journal of Money, Credit, and Banking 27, no. 3 (1995): 702-12.

Bodenhorn, Howard, and Hugh Rockoff. "Regional Interest Rates in Antebellum America." In Strategic Factors in Nineteenth Century American Economic History: A Volume to Honor Robert W. Fogel, edited by Claudia Goldin and Hugh Rockoff, 159-87. Chicago: University of Chicago Press, 1992.

Cagan, Philip, and Anna J. Schwartz. "The National Bank Note Puzzle Reinterpreted." Journal of Money, Credit, and Banking 23, no. 3 (1991): 293-307.

Champ, Bruce. The Underissue of National Banknotes During the Period 1875-1913. Unpublished Manuscript. 1990.

Champ, Bruce, Neil Wallace, and Warren Weber. "Resolving the National Bank Note Paradox." Federal Reserve Bank of Minneapolis Quarterly Review (spring 1992): 13-21.

Hammond, Bray. Banks and Politics in America from the Revolution to the Civil War. Princeton: Princeton University Press, 1957.

James, John. "The Conundrum of the Low Issue of National Bank Notes." Journal of Political Economy 84, no. 2 (1976): 359-67.

James, John. "A Note on Interest Paid on New York Bankers' Balances in the Postbellum Period." Business History Review 50, no. 3 (1976): 198-202.

Kuehlwein, Michael. "The National Bank Note Controversy Reexamined." Journal of Money, Credit, and Banking 24, no. 1 (1992): 111-26.

New York Assembly. "Annual Report of the Superintendent of Banks." Assembly Documents. Albany, 1835-1861.

New York Daily Times, various issues, 1850-1861.

New York Herald, various issues, 1850-1860.

Rolnick, Arthur, and Warren Weber. "Free Banking, Wildcat Banking, and Shinplasters." Federal Reserve Bank of Minneapolis Quarterly Review (fall 1982): 10-19. 